\title{
SOCIAL ENTREPRENEURS' STRATEGY MAKING IN SOCIETY 5.0
}

\author{
*Lutfihak ALPKAN ${ }^{\S}$ (Orcid ID: 0000-0002-7925-7102) \\ *Gaye KARACAY (Orcid ID: 0000-0003-2465-0297) \\ *Hakan ERTEN (Orcid ID: 0000-0003-0451-2380) \\ *Ardita MALAJ (Orcid ID: 0000-0002-7190-6905) \\ *Ali DOĞAN (Orcid ID: 0000-0001-5818-6109) \\ *Ahmet Onur YILDIZ (Orcid ID: 0000-0002-5252-8224) \\ *Istanbul Technical University \\ $\S_{\text {Corresponding author }}$
}

\begin{abstract}
Digital transformation has become a hot topic in our social and business life especially in the last decade. Today's newly forming socio-economic conditions require novel strategic perspectives both corporate and entrepreneurial aspects of business activities and their societal outcomes. Especially, such societal problems as unemployment, poverty, etc. require taking more responsibility for the solution of these common problems by all the actors of a society. Society 5.0 concept has emerged recently to indicate how to make use of the positive effects of digital transformation for the public wellbeing. Social entrepreneurs whose core motivation in doing business is to serve for the collective interest has come into prominence as an important agent in such a setting. This paper aims to develop propositions about the strategy making styles of social entrepreneurs at the age of Society 5.0 to study and discuss their opportunity evaluations, resource evaluations, participativeness and professionalism when compared to the strategic perspectives of top managers at large bureaucracies.
\end{abstract}

Keywords: Strategy, Society 5.0, Social Entrepreneur, Social Entrepreneurship

\section{INTRODUCTION}

Digital transformation or Industry 4.0 which represents very popular trends and paradigm changes seems to make very deep impacts on today's business and social life. Key elements of digitalization, i.e. machine learning, blockchain, cloud technologies, internet of things, cybersecurity, robotics, big data analytics etc. are becoming more visible and gaining more importance in our lives (Alpkan, Belgemen, Şenel, 2017). On one hand increasing opportunities in the dynamic local and global markets and rapid developments in automation technologies enable firms to develop at the same time quality improvement, cost reduction and customized flexible production leading to much higher overall performance. On the other hand, automated work procedures decrease the value of human labor leading to dejobbing and unemployment. The tradeoffs between advantages and disadvantages of this transformation including both business and social aspects may create newer advantageous (i.e. technopreneurs, monopolies, digital experts, etc.) and disadvantaged (unemployed youth, outmoded experts, classical publishers, etc.) classes or interest groups within the society. Moreover, in the present information society - also named Society 4.0 - sharing of knowledge, information, values, etc. and cooperating for the sake of the whole society are very limited and social problems (i.e. aging populations, immigration, brain drain, climate change, popular racism, youth unemployment, etc.) are generally underestimated by corporate strategists lacking any sense of responsibility toward their community and environment (Potocan, Mulej and Nedelko, 2020).

Japanese concept of Society 5.0 has recently emerged to make use of the positive effects of this rapid transformation for the sake of the whole society and to heal its negative side effects. According to Onday (2019) the objective of Society 5.0 is to make a human-driven society in which goals of societal difficulties are accomplished, and where individuals can appreciate a completely dynamic and agreeable high caliber of life. In such a desirable social environment, social entrepreneurs not only armed with an advanced expertise in digital technologies but also concerning for the betterment of their society, may come up with creative strategic ideas to deal with newer problems of their societal stakeholders while still making profit for their business shareholders. 
According to the previous research findings, the common motivation of social entrepreneurs is serving collective interests and creating social value for the public wellbeing (Austin, Stevenson, \& Wei-Skillern, 2006; Fisscher, Frenkel, \& Nijhof, 2005). Both social entrepreneurs and the private sector managers at the large and mature organizations pursue profit maximization for their organizations, however there is a huge difference how they plan and operate their operations. In other words, social entrepreneurs' approach to strategy development and implementation seem to be different from the top strategists at the large and mature organizations having established strategy making procedures. While social entrepreneurs try to develop newer combinations and solutions mostly for the disadvantaged members of the society, classical strategists at the top of large and mature organizations concentrate more on the inner organizational dynamics, current external competition, market share enlargement and public image. One may be more inclusive in terms of listening to the needs and concerns of various stakeholders, while the other one is more comprehensive in terms of scanning, planning, implementing and controlling (Alpkan, 2000). Intensive scanning of market information in the dynamic markets enable firms to pursue at the same time seemingly contradictory operational strategies of quality improvement, cost reduction and flexibility which then lead to overall organizational (operational, market and financial) performance (Alpkan, Ceylan, Aytekin, 2003). Similarly scanning intensity, planning flexibility, and participativeness increase quality performance while formalization and learning from failures contribute to innovativeness and productivity (Alpkan and Doğan, 2008).

Studies on the managers' decision making and risk taking patterns (e.g. Ali, 1993) are already conducted in the past literature. However, studies on the strategy making approaches of social entrepreneurs especially in Society 5.0 are very rare to our knowledge with the exception of some few recent studies on strategic choices in social enterprises by dealing mostly with the content of the strategy rather than the strategy making process. For instance, Moizer and Tracey (2010) compare the contradictory strategic trajectories of investing resources in business activity against investing resources in social action. In another study, Gras and Lumpkin (2012) investigate whether the strategies deemed important by social entrepreneurs contrast with those of commercial entrepreneurs in terms of strategic foci on products and markets. The present study in this concern aims to develop propositions about the strategy making styles of social entrepreneurs at the age of Society 5.0 to study and discuss their opportunity evaluations, resource evaluations, participativeness and professionalism when compared to large firms' strategists.

\section{SOCIAL ENTREPRENEURS' OPPORTUNITY EVALUATIONS}

The goal of Society 5.0 is to realize a society where economic growth and technological development exist for the purpose of the prosperity of the society rather than a selected minority. The technology developed should contribute to the solutions for societal challenges around the world (Fukuyama, 2018). Entrepreneurs, and specifically the social entrepreneurs can be considered as the actors to find the opportunity and satisfy the unmet needs which the public welfare system does not or cannot meet, thereby creating and sustaining social value (Dees, 1998; Nicholls \& Cho, 2006) while also seeking to increase individual entrepreneurial wealth (Peredo \& McLean, 2006). Social entrepreneurs look for opportunities to create not only valuable but also affordable service for especially underserved, neglected, or highly disadvantaged population that lacks financial means (Martin \& Osberg, 2007). According to Dees (1998) social entrepreneurs play the role of change agents in the social sector by recognizing and relentlessly pursuing new opportunities to serve the mission to create and sustain social value -not just private value.

From an entrepreneur's perspective, identifying and selecting right opportunities for new businesses are among the most important abilities (Stevenson et al., 1985), which is mostly driven by the strong selfefficacy trait as proposed by Krueger and Dickson (1994) and Krueger and Brazeal (1994). It is also suggested that perceived self-efficacy leads to optimism and a higher propensity to see opportunities rather than threats in any given situation (Neck and Manz, 1996). Besides the entrepreneur's personality traits, social networks and prior knowledge are also identified as antecedents of entrepreneurial alertness to business opportunities (Ardichvili, Cardozo and Ray (2003). For an entrepreneur, what may later be called an "opportunity" may appear as an "imprecisely-defined market need, or un- or under-employed resources or capabilities" (Kirzner, 1997). Opportunities arising from underutilized or unemployed resources, from technology or other types of proprietary knowledge or abilities, may turn into value creation (Schroeder et al., 1996). Entrepreneurs decide to start their ventures when they see the opportunity to utilize the resources to move from present, incomplete information to real opportunities (McGrath and Venkataraman, 1994). Willingness to generalize from small samples is a decision-making 
short cut that is common among entrepreneurs (Katz, 1992). Their data collection tactics help to identify new products and technologies at early stages and providing competitive advantage in favor of the entrepreneurs (Porter, 1980). The study by Busenitz and Barney (1997) suggests that entrepreneurs and managers in large organizations have different characteristics when it comes to opportunity identification.

Managers in large/mature organizations tend to make purely rational decision-making with an aggregated set of data. However, waiting to accumulate complete set of data in order to persuade others that their venture is indeed legitimate and rational, will most likely cause the opportunity they are seeking to exploit to be gone (Stevenson and Gumpert, 1985). Further, as large organizations tend to be characterized by more formal decision-making, such environments can be very rigid and highly against those who would like to act on biases and heuristic reasoning (Bazerman and Moore, 1994; Russo and Schoemaker, 1989).

Further, the economic feasibility and profitability of the social entrepreneurship opportunities may not be as attractive as existing projects of the large/mature organizations, considering that they already have a commitment to satisfy their existing customers, and cannot afford to divest from existing projects (Christensen, 2013). In this concern, social entrepreneurs are alert for the unmet needs of the disadvantaged members of their society and more prone to exploit advanced technologies to create affordable social value. Therefore, we propose that:

P1: Social entrepreneurs are more attracted by opportunities than the top managers in large \& mature firms while making strategy in Society 5.0

\section{SOCIAL ENTREPRENEURS' RESOURCE EVALUATIONS}

Resource scarcity is one of the major societal problems that people face in Society 4.0 together with similar other problems such as depletion of natural resources, global warming, growing economic disparity, immigration etc. According to "the super smart sustainable human centric society ideal" envisioned by the proponents of Society 5.0, improvements in information and communication technologies will help people enjoy a comfortable life (Fukayama, 2018; Shiroishi et al., 2018). In this concern, social entrepreneurship as an innovative approach for dealing with such complex social needs (Johnson, 2000) can be seen as one of the important and innovative social mechanisms in which valuable resources should be utilized with care for the sake of the whole society. In fact, we see this emphasis in the definition of social entrepreneurship: 'a process involving the innovative use and combination of resources to pursue opportunities to catalyze social change and/or address social needs' (Mair \& Marti, 2006). According to Dees (1998) social entrepreneurs act boldly without being limited by resources currently in hand. Moreover, Gras and Lumpkin (2012) indicate some strategic orientation differences between social entrepreneurs and commercial entrepreneurs in such a manner that the first focus on serving missed customers, marketing/promotion, and intellectual property while the latter focus on quality products and contemporary/attractive products.

Strategy making in the entrepreneurial mode, according to Mintzberg (1973) is growth-oriented and dominated by active search for new opportunities with tolerance for uncertainty. Entrepreneurs are in general risk taking, innovative, achievement oriented, optimistic and self-confident and they rely more on opportunities that they discovered than the normally necessary resources that they lack. Nonetheless some entrepreneurs who operate under significant resource limitations may demonstrate some higher levels of creativity in new product and service development than founders with ample resources for their enterprises (Fisher, 2012). Relying just on whatever available at hand and then creating something new from a variety of available resources - generally scarce- can be accomplished only if entrepreneurs and their stakeholders dedicate their full concentration, creativity, efforts and resources for a common or social cause. Likewise "Bricolage" as a concept emphasized mainly under the framework of resourcebased view (e.g. Penrose, 1959; Wernerfelt, 1984; Bojica et al, 2018) encompasses in social entrepreneurship a set of actions driven by the pursuit of existing and often scarce resources that can be combined to create innovative and valuable solutions that bring positive social change to markets and communities (Gundry et al, 2011). As such, bricoleurs have been described as tinkerers searching for new, unexpected cultural resources (Miettinen \& Virkkunen, 2005). Therefore, an organization's adoption of bricolage depends not only on their level of resources availability but also on the activities and cognitive abilities of the decision makers involved (Bojica et al, 2018). Recombination of available resources to create affordable social value necessitates also redefinition of strategic organizational 
resources by trying to develop newer social value propositions while leaving aside unethical, wasteful, and dysfunctional reproduction of the status quo.

Strategy making in the corporate mode, at the top management teams of mature and large bureaucracies, seems to necessitate more formal organizational policies and procedures that remove much of the flexibility enjoyed in earlier stages (Lester et al, 2009). Some organizations attempt to regenerate themselves as a reaction to the bureaucracy and lack of innovation that govern operations during the mature stage with the goal of returning the firm to a leaner (Quinn \& Cameron, 1983) and more innovative era (Miller \& Friesen, 1984). However, as Dodge \& Robbins (1992) state, top managers need to focus more attention and concentration on the internal problems of the large structure than external opportunities. Even if some top managerial concentration can be dedicated to the discovery of new opportunities, efforts to create newer solutions and combinations to exploit them would automatically rely still on long standing, over-utilized, and generally outmoded capabilities i.e. core rigidities that hinder new knowledge integration and innovation. These deeply rooted organizational rigidities that even new top managers cannot attempt to change are mainly originated from earlier professional specialization and well established organizational cultural norms and routines. Therefore, strategists in this type of organizations in general may easily develop biased evaluations by underestimating external developments including new technologies, changing customer expectations etc.; but over-relaying on current capabilities, over-concentrating on familiar technologies and current expertise (Leonard-Barton, 1992, 1993).

Consequently, social entrepreneurship encouraging the innovative and creative recombination of strategic resources has an important role in Society 5.0. Strategy making processes relying more on internal strategic resources than external developments and opportunities seem to be less practical and advisable in this era of rapid transformation. As for the well-established large and mature firms, to tackle with the challenge of redefining their strategic opportunities and recombining their large and sometimes inert resources to create social value seem to be much more difficult than visionary small entrepreneurial companies specifically established with a specific social cause and limited but dynamic resource base. In the light of these considerations, we formulate the following proposition:

P2: Social entrepreneurs rely on strategic resources less than the top managers in large \& mature firms while making strategy in Society 5.0

\section{SOCIAL ENTREPRENEURS' PARTICIPATIVE LEADERSHIP}

Society 5.0 represents the use of advances technologies and products for connection of people and things and sharing of all sorts of knowledge and information in creation of new social and business value (Shiroishi,2018; Nakanishi,2019). Social entrepreneurs as the change agents pursuing a humane-oriented vision are concerned more about attempting to create positive social impact for their community while making and implementing their organizational strategy. In this concern participative leadership in the form of involving other people i.e. organizational and societal stakeholders into the decision making processes suits very well with the notion of social entrepreneurship. Praszkier and Nowak (2012) describe social entrepreneurs as participative leaders who promote such positive perceptions, attitudes and intentions as trust, support, cooperation, inspiration etc. and then draw on the ideas of all members to develop creative solutions. Accordingly, Coker and colleagues (2017) propose that participative leadership culture will generate more social entrepreneurial activity. Playing at the same time the role of "social agents" who exhibit a heightened sense of accountability to the societal constituencies served and for the social outcomes created and the role "entrepreneurs" who possess a high tolerance for ambiguity and learning how to manage risks for themselves and others (Dees, 1998) oblige into some extent the social entrepreneurs to consult with every possible source of creative ideas.

The practice of participation by gathering the inputs of participating stakeholders during the alternatives generation and/or idea selection phases of strategy making would produce informational benefits for also the strategists of large centralized companies (Mack and Szulanski, 2017). Especially in turbulent environments, strategy making appears likely to involve more people than "centralized elite" (Whittington, Douglas, Ahn, Cailluet, 2017). Yet, large number of different types of participants in large companies may have diverse preferences, and the reconciliation of this diversity may be very difficult, if not impossible. Therefore, allowing peripheral participants to speculate about some details of some alternative ideas by engaging in deeper and prolonged conversations may not be very practical and 
productive while final decisions and selections would be done at the end only by a small group of corporate elites (Mack and Szulanski, 2017) who concern more about mid and long term goals of overall profitability, market share and survival.

Strategic orientation differences, hierarchical stratification and social distance in large and centralized bureaucracies may easily alienate strategists from others while the vision to combat with social inequalities in the mind of the social entrepreneurs may help them to be more inclusive and participative especially for needy groups of people who have invested their personal faith in the social enterprise (Steinerowski, Jack, and Farmer, 2008). Based on the arguments mentioned we propose that:

P3: Social entrepreneurs encourage participation more than the top managers in a large \& mature firms while making strategy in Society 5.0

\section{SOCIAL ENTREPRENEURS’ PROFESSIONALISM}

Social entrepreneurs have already become highly visible agents of social change by applying innovative and cost-effective methods to address social problems like as poverty or inequality that have defied traditional solutions (Cox and Healey, 1998) which is something especially necessary at the age of Society 5.0. As Mintzberg (2002) has already pointed out, corporations are not only economic entities but also social institutions that must justify their existence by their overall contribution to society. However, corporate professionals particularly managers and specialized staff in the large organizations in general tend to establish a cognitive base and legitimization for their occupational autonomy; meanwhile organizational success is not completely achieved since compromise with nonprofessionals is neglected (DiMaggio and Powell, 1983). Well established formal mechanisms of professional education, together with professional networks and associations, breed and justify professional solidarity on one hand, but weakens ties with and concerns for needy people on the other. Especially at large organizations professional elite still retain their strategic position of top strategists and satisfy their need for power while social entrepreneurs at small organizations risk their not-so-much professionally legitimized carriers in search for creative solutions to social problems. Still the latter may find social legitimacy and achievement motivation with the possible satisfaction of those in need at the end of social innovation efforts.

Top managers at large bureaucracies set organizational norms and strategic orientations in line with professional norms, professional expertise, environmental pressures, their own past experiences, etc. This credibility of professionalism among other factors may work in ordinary environments that necessitate close and daily planning, coordination and control of routine tasks, operations, etc. with the help of both managers' own professional expertise and other professionals' remarks and suggestions. However, when we compete in more dynamic environments, an organization's ability to integrate, build, and reconfigure internal and external resources/competences in order to address and shape rapidly changing environmental conditions become much more vital (e.g. Teece, 1990; Teece 2007) and just relying on professional expertise and information turn to be insufficient. Moreover, large organizations if dominated by a group of professionals as top strategists conforming to similar professional norms can produce less risky and more standardized strategies similar with other similar professionally legitimized organizations. In times of stable growth based on professional expertise, this conformity approach may prove to be very practical and comfortable; but what about turbulent times of rapid and chaotic transformation?

The necessity to craft creative strategies in Society 5.0 where some professions begin to disappear or lose their importance and the main focus of transformation shifts from the manufacturing processes to social context, oblige both social entrepreneurs and top professionals to come together and concentrate on matching newest technological developments with unmet social needs beyond already defined professional, organizational or sectoral borders. While being so obedience to current professional norms, ceremonies and groupings may also lose its practicality and even legitimacy for the sake of much more inclusive and productive solidarities among societal stakeholders coming from very diverse backgrounds. In brief uncertainty and change in the professional life begin to convince strategists to behave as if social entrepreneurs who try to adapt more but conform less. Accordingly, we propose that:

P4: Social entrepreneurs try to conform with professional norms less than the top managers in large \& mature firms while making strategy in Society 5.0 


\section{CONCLUSION}

Social entrepreneurs aim to create social value by providing social benefit with the innovative solutions they develop for various societal problems. In order to achieve their goals, social entrepreneurs need not only financial resources but also solid business strategies that enable them to successfully perform. Since social entrepreneurs are concerned mostly about creating positive social impact for their community while making and implementing their organizational strategy, the way they develop their business strategy requires a specific and unique approach that would help them to concentrate on providing solutions to unmet societal needs. In contrast, the strategy formulation process in the corporate mode by the top managers of mature and large bureaucracies rely mostly on formal and mostly standard organizational policies and procedures that principally focus on enabling profit maximization.

The present study provides propositions for strategy making styles of social entrepreneurs at the age of Society 5.0 in particular to their opportunity evaluations, resource evaluations, participativeness and professionalism when compared to the top managers of mature and large bureaucracies. Accordingly, based on our developed propositions about strategy making differences between social entrepreneurs and large firm strategists in Society 5.0, we assert that social entrepreneurs are more attracted by opportunities but rely on strategic resources less; they also encourage participation more but try to conform with professional norms less. These differences make social entrepreneurial organizations more advantageous in rapid learning by opportunity seeking and risk taking while consulting with other social stakeholders for the betterment of the society. On the other hand, strategists in large and mature bureaucracies rely more on other critical advantages i.e. accumulation of strategic resources, professional expertise, organizational legitimacy, etc.

As for the practical implications of our study, we may relate the strategy making differences to different organization types and strategic orientations. Serving to different aspects of strategic visions, different strategic styles may help also each other while trying to produce common societal value. This requires synergetic efforts among social entrepreneurs and corporate strategists concerning with both organizational and societal prosperity at the same time. Collaboration and solidarity among different strategic units i.e. startups, private corporations, public organizations, civil society organizations, etc. complementing each other in terms of strategic resources and opportunities may produce creative and sustainable social value much more effectively and efficiently. As for further research implications, we may suggest that other possible dimensions of strategy making may be added in future studies to compare among different strategic decision makers. In addition, to validate similar propositions in the form of related hypotheses, empirical studies may also be conducted. The social impacts of different strategy making and implementation approaches and possible ways to combine them for a common societal cause may also be studied in further studies.

We emphasize in this study that developing organizational and societal strategies to cope with digital transformation is a must for every kind of organizations in today's business life. Affordable and creative solutions for the present and future problems of especially disadvantageous members of the society necessitate common synergetic efforts among different strategic initiatives. Different strategy making approaches in different types of organizations may find their separate way by building strategic advantages either relying on opportunities or resources more, or by building organizational legitimacy either consulting with stakeholders or conforming to professional norms. However, joint social projects to be conducted with the collaboration of different societal agents providing necessary and complementary entrepreneurial and corporate advantages would be more beneficial for the whole society. To conclude, crafting effective and efficient strategies in Society 5.0 is a real challenge and diverse approaches either separately or jointly need to be developed in order to adapt and prosper. 


\section{REFERENCES}

Ali, A. (1993), "Decision-Making Style, Individualism, and Attitudes toward Risk of Arab Executives", International Studies of Management \& Organization, 23 (3): 53-73.

Alpkan, L. (2000), Strateji Belirleme Sürecinin Kapsamlılığı”, Doğuş Üniversitesi Dergisi 1 (2): 1-19.

Alpkan, L., Belgemen, M., Şenel, A. (2017), A Discussion about the Effects of Artificial Intelligence on the Social Life, 7th International Conference on Leadership, Technology, Innovation and Business Management, Marmaris, Turkey, The European Proceedings of Social \& Behavioural Sciences, 287-296.

Alpkan, L., Ceylan, A., Aytekin, M. (2003), Performance Impacts of Operations Strategies: A Study on Turkish Manufacturing Firms", International Journal of Agile Manufacturing, 6 (2): 57-65.

Alpkan, L., Doğan, T. (2008), Stratejik Planlama Süreci Bileşenlerinin Firma Performansına Etkileri, Kocaeli Üniversitesi Sosyal Bilimler Enstitüsü Dergisi, 16 (2): -47.

Ardichvili A., Cardozo R., Ray S. (2003), A Theory of Entrepreneurial Opportunity Identification and Development, Journal of Business Venturing, 18 (1): 105-123.

Austin, J., H., Stevenson, J., Wei-Skillern (2006). Social and Commercial Entrepreneurship: Same, Different, Or Both?, Entrepreneurship Theory and Practice, 30 (1): 1-22.

Bazerman, M. H., \& Moore, D. A. (1994), Judgment In Managerial Decision Making (p. 226). New York: Wiley.

Bojica, A. M., Ruiz, J., Enez, J., Ruiz Nava, M., Fuentes-Fuentes (2018). Bricolage and growth in social entrepreneurship organisations. Entrepreneurship and Regional Development 30 (3-4): 362-389.

Busenitz, L.W., Barney, J.B (1997), Differences Between Entrepreneurs and Managers In Large Organizations: Biases And Heuristics In Strategic Decision-Making, Journal of Business Venturing, 12: 9-30.

Christensen, C. (2013). Innovator's Dilemma. Boston: Harvard Business Review Press

Coker, K., Flight, R., Valle, K. (2017), Social Entrepreneurship: The Role of National Leadership Culture, Journal of Research in Marketing and Entrepreneurship, 19 (2): 125-139

Cox, A., Healey, J. (1998), Promises to The Poor: The Record Of European Development Agencies. Poverty Briefings, vol. 1. Overseas Development Institute, London.

Dees, J.G. (1998), The Meaning Of Social Entrepreneurship, available at http://faculty.fuqua. duke.edu/centers/case/files/dees-Se.pdf

DiMaggio, P. J., Powell, W. (1983), The Iron Cage Revisited: Institutional Isomorphism And Collective Rationality In Organizational Fields, American Sociological Review, 48: 147-160.

Dodge, H. R., Robbins, J.E. (1992). An Empirical Investigation Of The Organizational Life Cycle Model For Small Business Development And Survival, Journal of Small Business Management, 6 (1), 27-37.

Fisher, G. (2012), Effectuation, Causation and Bricolage: A Behavioral Comparison of Emerging Theories in Entrepreneurship Research, Entrepreneurship Theory \& Practice, 36 (5): 1019- 1051.

Fisscher, O., Frenkel, D., Lurie, Y., Nijhof, A. (2005). Stretching The Frontiers: Exploring The Relationships Between Entrepreneurship And Ethics. Journal of Business Ethics, 60(3): 207-209.

Fukuyama, M. (2018), Society 5.0: Aiming For A New Human-Centered Society, Japan SPOTLIGHT, July/Aug 2018, Japan Economic Foundation

Gras, D., Lumpkin, G. (2012) Strategic Foci in Social and Commercial Entrepreneurship: A Comparative Analysis, Journal of Social Entrepreneurship, 3 (1): 6-23

Gundry, L. K., Kickul, J. R., Griffiths, M. D., Bacq, S. C. (2011). Creating Social Change Out of Nothing: The Role of Entrepreneurial Bricolage In Social Entrepreneurs' Catalytic Innovations, Advances in Entrepreneurship, Firm Emergence and Growth, 13 (7): 1-24. 
Johnson, S. (2000). Literature Review On Social Entrepreneurship, Canadian Centre for Social Entrepreneurship

Katz, J. A. (1992), A Psychosocial Cognitive Model of Employment Status Choice, Entrepreneurship Theory and Practice, 17 (1): 29-37.

Kirzner, I., (1997), Entrepreneurial Discovery and The Competitive Market Process: An Austrian Approach. J. Econ. Lit. 35, $60-85$.

Krueger, N., Dickson, P. R. (1994). How Believing In Ourselves Increases Risk Taking: Perceived Self-Efficacy and Opportunity Recognition. Decision Sciences, 25(3): 385-400.

Krueger, N. F., Brazeal, D. V. (1994). Entrepreneurial Potential and Potential

Entrepreneurs. Entrepreneurship Theory and Practice, 18 (3): 91-104.

Lester, D. L., Parnell, J. A., Menefee, M. L. (2009). Organizational life cycle and innovation among entrepreneurial enterprises, Journal of Small Business Strategy, 19 (2): 37-50.

Leonard-Barton, D (1992), Core Capabilities And Core Rigidities: A Paradox In Managing New Product Development. Strategic Management Journal, 13: 111-125.

Leonard-Barton, D. (1995), Wellsprings of Knowledge: Building and Sustaining the Sources of Innovation. Boston: Harvard Business School Press

Mack, D.Z., Szulanski, G. (2017), Opening Up: How Centralization Affects Participation and Inclusion in Strategy Making, Long Range Planning.

Mair, J., Martì, I. (2006), Social Entrepreneurship Research: A Source of Explanation, Prediction, and Delight, Journal of World Business, 41, pp. 36-44

Martin, R.L., Osberg, S. (2007), Social Entrepreneurship: The Case for Definition, Stanford Social Innovation Review. Spring 2007.pp.29-39.

McGrath, R., Venkataraman, S. (1994), Present Promise, Future Payoff? The Nature of Expectations in Internal Corporate Ventures. Working paper, Sol Snider Entrepreneurial Center, Wharton School, University of Pennsylvania

Miettinen, R., Virkkunen, J. (2005), Epistemic objects, artefacts and organizational change. Organization, $12(3): 437-456$

Miller, D., Friesen, P (1984), A Longitudinal Study of the Corporate Life Cycle. Management Science, 30: 1161-1183.

Mintzberg, H. (2002), Beyond Selfishness. Sloan Management Review 44 (1): 67-74.

Mintzberg, H. 1973. Strategy making in three modes. California Management Review, 16(2): 44-53.

Moizer, J., Tracey, P. (2010). Strategy Making In Social Enterprise: The Role of Resource Allocation and Its Effects On Organisational Sustainability, Systems Research and Behavioural Science, 27: 252-266.

Nakanishi, H. (2019), Modern Society Has Reached Its Limits "Society 5.0" Will liberate us, World Economic Forum, Davos.

Neck, C. P., Manz, C. C. (1996), Thought Self-Leadership: The Impact Of Mental Strategies Training On Employee Cognition, Behavior, And Affect, Journal of Organizational Behavior, 17(5): 445-467.

Nicholls, A., Cho, A.H. (2006), Social Entrepreneurship: The Structuration of A Field, in Nicholls, A. (Ed.): Social Entrepreneurship - New Models of Sustainable Social Change, Oxford University Press, Oxford. 99-118.

Onday, O. (2019). Japan's Society 5.0: Going Beyond Industry 4.0, Business and Economics Journal, 10 (2): $1-6$.

Penrose, E. (1959), The Theory Of The Growth Of The Firm. New York: John Wiley.

Peredo, A.M., McLean, M. (2006). Social Entrepreneurship: A Critical Review of The Concept. Journal of World Business, 41, 56-65. 
Porter, M. E. (1980), Competitive Strategy: Techniques for Analyzing Industries and Competitors. New York: The Free Press.

Potočan, V., Mulej, M., Nedelko, Z. (2020), Society 5.0: Balancing of Industry 4.0, Economic Advancement and Social Problems, Kybernetes, Vol. ahead-of-print, https://doi.org/10.1108/K-12-20190858

Praszkier, R., Nowak, A. (2011). Social Entrepreneurship: Theory and Practice. New York, NY: Cambridge University Press.

Quinn, R, Cameron, K. (1983), Organizational Life Cycles And Shifting Criteria Of Effectiveness: Some Preliminary Evidence. Management Science, 29 (1): 33-41.

Russo, J. E., Schoemaker, P., (1989). Decision Traps: Ten Barriers To Brilliant Decision-Making And How To Overcome Them, Fireside Publishing.

Schroeder, R.G., Buckman, J., Cardozo, R.N. (1996), New Value Creation: The Next Development In Quality Management. White paper, Carlson School of Management, University of Minnesota, Minneapolis.

Shiroishi, Y., Uchiyama, K., Suzuki, N. (2018), Society 5.0: For Human Security and Well-Being, Computer, 51(7): 91-95.

Steinerowski, A., Jack, S., Farmer, J. (2008), Who Are The Social 'Entrepreneurs' and What Do They Actually Do?. Babson College Entrepreneurship Research Conference (BCERC) 2008, Frontiers of Entrepreneurship Research.

Stevenson, H., Gumpert, D. (1985), The Heart of Entrepreneurship, Harvard Business Review, 63 (2): 8594.

Stevenson, H.H., Roberts, M.J., Grousbeck, H.I. (1985), New Business Ventures and the Entrepreneur. Irwin, Homewood, IL.

Teece, D.J. (1990), Firm Capabilities, Resources, and The Concept of Strategy. Center For Research In Management, University of California, Berkeley, Working Paper 90-8.

Teece, D.J. (2007), Explicating Dynamic Capabilities: The Nature and Microfoundations of (Sustainable) Enterprise Performance, Strategic Management Journal, 28(13): 1319-1350.

Wernerfelt, B. (1984), A Resource-Based View of The Firm, Strategic Management Journal 5 (2): 171180.

Whittington, R., Yakis-Douglas, B., Ahn, K., \& Cailluet, L. (2007), Strategic Planners In More Turbulent Times: The Changing Job Characteristics Of Strategy Professionals, 1960-200, Long Range Planning, 50: $108-119$. 